\title{
Organ Donation among Malaysian: The Malay Dilemma toward Social Development
}

\author{
Nazni Noordin ${ }^{1}$, Zaherawati Zakaria ${ }^{1}$, Adnan Aminuddin ${ }^{1}$, Mahazril' Aini Yaacob ${ }^{1}$, Mohd Zool Hilmie \\ Mohamed Sawal' ${ }^{2}$, Mohd Shamsul Daud ${ }^{2}$, Azrul Shahimy Mohd Yusof ${ }^{3} \&$ Kamarudin Ngah $^{4}$ \\ ${ }^{1}$ Faculty of Administrative Science \& Policy Studies, Universiti Teknologi MARA, Merbok, Kedah, Malaysia \\ ${ }^{2}$ Faculty of Information Management, Universiti Teknologi MARA, Merbok, Kedah, Malaysia \\ ${ }^{3}$ Faculty of Language Studies, Universiti Teknologi MARA, Merbok, Kedah, Malaysia \\ ${ }^{4}$ Pusat Penyelidikan Dasar dan Kajian Antarabangsa (CenPRIS), Universiti Sains Malaysia (USM), Pulau \\ Pinang, Malaysia
}

Correspondence: Zaherawati Zakaria, Faculty of Administrative Science \& Policy Studies, Universiti Teknologi MARA, P. O Box 187, 08400 Merbok, Kedah, Malaysia. Tel: 60-4-456-2519. E-mail: zaherawati@kedah.uitm.edu.my

\author{
Received: April 1, $2012 \quad$ Accepted: May 7, $2012 \quad$ Published: August 1, 2012 \\ doi:10.5539/ass.v8n10p8 URL: http://dx.doi.org/10.5539/ass.v8n10p8
}

\begin{abstract}
Organ donation among the world community today is not a new phenomenon. The noble act of organ donation by donors that at times, has no blood relations has enabled many patients with chronic diseases to earn a second chance in life. The same scenario also takes place in Malaysia in which awareness of organ donation to help parties in need is not new. Many citizen of Malaysia is aware that their contribution gives "new life" to the needy. This little "scarifies" indirectly shows that Malaysian people put a high value for the social development in their country. The Malays in Malaysia is the largest ethnic group, but unfortunately, the statistics show that the Malays are the least to sign up for organ donation. Thus, the objective of this study is to identify the causes that prevented them from doing so. This study was conducted by taking into account three factors; religion, awareness, as well as perception or views on organ donation willingness among the Malays. Of the three factors studied, only two significant factors contributed to the main question of why the Malays shy away from organ donation and they are religion and perception. This shows that the Malays are aware that organ donation is a noble practice, but limited perception and knowledge of religion limit their participation. Therefore, it is recommended that a comprehensive discussion among religious leaders in changing the perception and explain the laws of religion on the issue of organ donation is carried out continuously in various mediums so that the awareness of the Malays in organ donation can be fully utilized for the benefit of everyone.
\end{abstract}

Keywords: organ, organ donor, organ donation, religion, awareness, perception

\section{Introduction}

It is often heard on radio channels and television stations, printed medias and websites such as social networking sites like facebook and the like about the suffering of patients requiring organ donors to continue living. Organs such as corneas, kidneys, hearts and more are the main organs needed by people to live. This current situation is a serious concern in which the numbers of patients who need these organs are increasing while the number of donors who come forward to donate is significantly lower, and thus unable to fulfill the patients' need. Questions may come to mind about our community awareness of the needs, whereas at the moment we keep on thinking about the answer to these questions, thousands of lives in need of organs is at stake as these patients condition become worse day by day. It is heart-wrenching to think that some of them are counting to the end of their days as the expected donor does not appear as expected. The patients consisted of various categories of race, age, and gender, who suffer while waiting for generous donors to come forward to donate organs suitable for them. However, to obtain a suitable donor is not an easy thing for many of society find it easier to donate money than the organ itself. Thus, a study is conducted for the purpose to identify the factors of why the society finds it difficult to register as organ donors, especially among the Malays as the Malays donates the least than the Chinese and Indians. 
Statistics obtained from the National Transplant Resource Centre, Kuala Lumpur (2010), found that the Malays registered the least as organ donors compared to other major communities of in Malaysia China \& India. According to the statistics (Table 1) organ donation among the Malay community contributed only $6.36 \%$ of the total organ donation from $2000-2010$ as compared to the Chinese and Indians in which theirs was $61.86 \%$ and $31.78 \%$. This figure raises a question mark that lead to the researchers' initiative to initiate a study to identify the main factors that contribute to these scenarios.

Table 1. Organ \& Tissue Donors statistics provided by the National Transplant Resource Centre, Hospital Kuala Lumpur, (Source: New Straits Times, October 16, 2010)

\begin{tabular}{|c|c|c|c|c|c|c|c|c|c|c|c|c|}
\hline Year & 2000 & 2001 & 2002 & 2003 & 2004 & 2005 & 2006 & 2007 & 2008 & 2009 & 2010 & $\begin{array}{c}\text { Total } \\
\text { number of } \\
\text { donors \& } \\
\text { Percentage }\end{array}$ \\
\hline Malays & 3 & 1 & - & - & 1 & 1 & 1 & 5 & - & 3 & - & $\begin{array}{c}15 \\
(6.36 \%)\end{array}$ \\
\hline Chinese & 6 & 16 & 13 & 14 & 14 & 5 & 12 & 14 & 17 & 16 & 19 & $\begin{array}{c}146 \\
(61.86 \%)\end{array}$ \\
\hline Indians & 3 & 3 & 14 & 8 & 1 & 7 & 11 & 3 & 6 & 10 & 9 & $\begin{array}{c}75 \\
(31.78 \%)\end{array}$ \\
\hline & & & & & Total & & & & & & & 236 \\
\hline
\end{tabular}

The objective for this study is to identify the relationship between religion, awareness, perception, or insight which leads to a shortage of donors in the Malay community and also to determine which is the major factor among the three factors that contributed to the shortage of organ donors in the Malay community.

Results from this study will provide a useful input to all Malaysians, especially the Malay community's understanding on the main factor that leads to a lack of organ donors among them. Based on these inputs, it is hoped that to some extent, the perception of the Malays on organ donation can be changed as organ donation itself is a noble act. The act itself is regarded as a social responsibility that reflects their belief by helping others in this world.

This study may pave the way for improvements by the government to act more actively in creating awareness to all Malaysians on the importance of organ donation in creating a society that is mutually helpful and share their joy and sorrow that is based on the "1Malaysia" concept. It involves an emphasis on awareness programs, but also to a level that is more significant by creation of certain policies in order to increase the number of donors, such as introducing certain benefits to organ donors. This could be a motivational during decision making. As for non-governmental organizations, related campaigns should be intensified to support the government along with sponsorships of organizations that has the potential to scaffold such efforts.

\section{Phenomenon}

The Malay community on the issue of organ donation based on three aspects of the variables associated with this issue, in which they are religion, awareness and perception / opinion. These three aspects are known as the Independent Variables (IV) and they have an impact on the number of organ donations among the Malay community. In view of organ donation as an important issue nowadays, the researchers explore further on whether the people is aware of that fact. The independent Variable (IV) is correlated with the Dependent Variable (DV), which refers to the scope of the study of organ donation among the Malays. Any changes that occur in the Independent Variable (IV) will affect the findings of the Dependent variable (DV) itself. Religion is an important factor that affects an individual's decision to become an organ donor, although religion itself is never forbid them to do so (Bilgin, 1999).

The researchers described awareness as being associated with the knowledge of a person. Armed with the knowledge available to every human being, they are able to respond appropriately to any change, renewal, or any scenario that is happening around them. This study reveals the respondents' awareness based on the knowledge that they have regarding this issue. 
Awareness raises an individual's desire to do something, including organ donation. However, it will only be innately available if they have little knowledge of something that is to be done. Gupta, A., Jain, S., Jain, T., \& Gupta K., (2009) states that knowledge is a major step in raising awareness among the society. This means that through education, they will realize the importance of an issue than those who are uneducated.

In addition, perception, insight or acceptance of organ donation is closely related to attitude in which they influence the people around them, especially close family members. The decision to participate as an organ donor can be overshadowed by the insistence of family members based on factors leading to the interest of their fellow family members. It includes numerous assumptions that affect the donors themselves and also the immediate family members. Nevertheless, it is unhealthy to be negative without thinking of the sacrifice and the virtue in the effort in helping people who really need organ donations. Educational factors play an important role in countering this. H. Bilgel, G. Sadikoglu and N. Bilgel (2006) states that in Turkey, many factors can influence the attitudes of people on the organ donation such as age, religion and education.

Talking about organ donation, the Malay community itself is not spared from their traditions and dilemma. Both of these categories showed a clear expression of the lack of interest in the Malay community to donate organs. Perception or opinion is categorized as a tradition (Myth) because the word itself constitutes the story or traditional practices that affect the trust and the trigger to a natural phenomenon. In addition, religion and awareness also part of the dilemma faced by the Malays. Dilemma can be defined as any difficulty or hardship faced in any situation. It also refers to a situation where they face difficulty in making a choice or decision.

The Malays face the dilemma of being unsure whether their religion allows them to make organ donations. Some people are not clear about the fact that their religion allows them to perform organ transplants in order to save other human lives. At the same time, a low level of awareness of this issue marginalized this issue and prevented any effort or appropriate solution to be proposed. Organ transplants are generally accepted as a method or solution to the final stage of organ failure in the human body, as reviewed by H. Khalaf, M.I.M. Al Sebayel (2004). Organ donation activities may take place when either the donor is alive or had died, but it depends on their own consent.

In this study, three hypothesis were constructed which is the first one, there is significant relationship between religious factors and the shortage of organ donors among the Malays, followed by there is a correlation between awareness and the shortage of organ donors among Malay and last one, there is a significant relationship between perception and the shortage of organ donors among Malays.

\section{Research Methodology}

The case study was done in the City Council of Sungai Petani (MPSPK) Kedah in which the specific location was at South Tesco of Sg Petani and North Tesco of Sungai Petani as it is easy for the researchers to get the respondents. Only the Malays were selected as respondents via Simple Random Sampling. A total of 100 sets of questionnaires were distributed by the researchers in which 50 sets are for respondents in South Tesco of Sg Petani and the rest in North Tesco of Sg Petani. The data were collected in October 2011. A research design was developed to collect data related to the issues discussed and then analyzed to find a solution to a related issue. The study was conducted using the descriptive approach that allows each issue to be described based on the individual's view of the selected respondents. This study used survey questionnaires as an instrument for data collection purpose. The survey form was developed by taking into account various factors as based on the IV and DV of the research. Nominal scale measurement indicates where a variable is measured qualitatively according to a specific category. In this study, the nominal scale is used to obtain demographic information, such as age and gender. The use of an interval scale allows the researchers to carry out arithmetic operations of the data obtained from the respondents. By using this scale, the researchers measure the elements' variables based on the Forces Rating Scale (Table 2) which was prepared by the researchers to be determined by the respondents as described by Malhotra (2004). The respondents are asked to express their views on an item based on the statements provided. The information is later obtained then analyzed based on the positive and negative aspects depending on the question or statement that will help the researchers to make conclusions based on the findings.

Table 2. Forces rating scale

\begin{tabular}{cccc}
\hline 1 & 2 & 3 & 4 \\
\hline Strongly Disagree & Disagree & Agree & Strongly Agree \\
\hline
\end{tabular}

(Malhotra, 2004) 


\section{Collection \& Data Analysis}

Questionnaires were used to obtain research data. It formed the basis of the variable that was identified as the factors that led to the problems of the shortage of organ donors among the Malays. Using this data collection method, the respondents were given a period of time to provide input based on their rationale. The data collected were then quantitatively analyzed using the Statistical Package of Social Science (SPSS). This statistical software will process and formulate the obtained data as a whole to determine the relationship between the variables involved such as the Independent Variable (IV), which include aspects of religion, awareness, perception; with the Dependent Variable (DV) which is the shortage of organ donors among the Malays. The data were analyzed according to the methods or techniques such as Descriptive Analysis, Pearson Correlation, Multiple Regression Analysis, and Cronbach's alpha as follows (Table 3):

Table 3. Data analysis method

\begin{tabular}{|c|c|c|}
\hline \# & Item & Method \\
\hline 1 & Section A, the respondents' demographic. & Descriptive Analysis \\
\hline 2 & $\begin{array}{l}\text { Research Objective 1: To identify the relationship between religious factors, } \\
\text { awareness and perception / opinion which lead to the lack of donors in the } \\
\text { Malay community. }\end{array}$ & Pearson Correlation \\
\hline 3 & $\begin{array}{l}\text { Research Objective 2: To determine the main factor between the three } \\
\text { factors that contributed to the shortage of organ donors Malay community. }\end{array}$ & $\begin{array}{l}\text { Multiple Regression } \\
\text { Analysis }\end{array}$ \\
\hline 4 & $\begin{array}{l}\text { A Pilot Study was conducted to test the accuracy and validity of the } \\
\text { questionnaire. }\end{array}$ & Cronbach's alpha \\
\hline
\end{tabular}

Descriptive Statistics are used to make a general observation of the obtained data. Overall observation is important as it give an indication of the trend of the data obtained in accordance with its own diversity as observed in terms of gender and age of the respondents. The Pearson Correlation method is used to measure the relationship between the variables involved in the study. In this study, it is used to identify the existence of a significant correlation between the Independent Variable (IV) of religion, awareness and perception / opinion with the Dependent Variable (DV) which is the shortage of organ donors Malays. Correlation of a variable is significant if the alpha value, $\mathrm{P}$ is lower than $0.05(\mathrm{P}<0.05)$

Multiple Regression Analysis was used to determine the most significant factor between the three factors that was determined based on the Independent Variable (IV) in this study. Cronbach Alpha Method is used during the pilot study to verify the accuracy or validity of the survey conducted. By using this method, the researchers randomly select a total of 20 respondents. Maslach, Jackson \& Leiter (1996) stated that the validity of the questionnaire is determined or measured by Cronbach Alpha analysis method in which if the accuracy or validity of the analysis exceed 0.6, the higher the accuracy and the validity of such data. Based on the Pilot Test (Table 4 $\&$ Table 5) that was done in this study, it verifies the validity \& accuracy of data collected used as input in the study.

Table 4. Cronbach alpha result for dependent variable $(d v)$

Organ donation among the Malays

\begin{tabular}{ccc}
\hline Cronbach Alpha & $\begin{array}{c}\text { Cronbach Alpha Based of Adjusted } \\
\text { Item }\end{array}$ & Item Total \\
\hline .718 & .718 & 8 \\
\hline
\end{tabular}

Table 5. Cronbach alpha result for independent variable (IV)

Religion

\begin{tabular}{lll}
\hline Cronbach Alpha & $\begin{array}{l}\text { Cronbach Alpha Based of Adjusted } \\
\text { Item }\end{array}$ & Item Total \\
\hline .647 & .649 & 5
\end{tabular}

Awareness'

\begin{tabular}{lll}
\hline Cronbach Alpha & $\begin{array}{l}\text { Cronbach Alpha Based of Adjusted } \\
\text { Item }\end{array}$ & Item Total \\
\hline .712 & .677 & 6 \\
\hline
\end{tabular}


Perception

\begin{tabular}{lll}
\hline Cronbach Alpha & $\begin{array}{l}\text { Cronbach Alpha Based of Adjusted } \\
\text { Item }\end{array}$ & Item Total \\
\hline .711 & .707 & 7 \\
\hline
\end{tabular}

\section{Findings and Analysis of Data}

This section focuses on the findings as based on the analysis of questions and answers that were distributed to respondents. For that purpose, the researchers used descriptive analysis, regression and Pearson correlation to answer the research objectives. The first objective is to identify the relationship between the Independent Variables of religion, awareness and perception with the dependent variable which is the lack of organ donors among the Malay community. The second objective was to determine which of the three Independent Variables is the major contributor to a shortage of organ donors in the Malay community.

\subsection{Description of Respondents' Profile}

At the beginning of the study, 100 sets of questionnaires were distributed to the respondents but only 74 complete sets of forms were returned to the researchers. The remaining forms were not returned, or returned incomplete. The first element of the study is of gender. $24.3 \%$ of the respondents were males and $75.7 \%$ were females as shown in Table 6.

Table 6. Respondents' gender

\begin{tabular}{lll}
\hline Gender & Frequency & Percentage \\
\hline Male & 18 & 24.3 \\
Female & 56 & 75.7 \\
Total & 74 & 100.0 \\
\hline
\end{tabular}

In term of age (Table 7), the majority of the respondents were those aged between 18-29 years and they contributed $89.2 \%$ of the total respondents. This is followed by $30-39$ years of age and $50-59$ years respectively and they accounted for $4.1 \%$ of the total respondents, while $2.7 \%$ of the respondents were $40-49$ years old.

Table 7. Respondents' age

\begin{tabular}{lll}
\hline Age & Frequency & Percentage \\
\hline $18-29$ years old & 66 & 89.2 \\
$30-39$ years old & 3 & 4.1 \\
$40-49$ years old & 2 & 2.7 \\
$50-59$ years old & 3 & 4.1 \\
Total & 74 & 100.0 \\
\hline
\end{tabular}

5.2 Findings for the Hipotesis

H1: There is significant relationship between religious factors and the shortage of organ donors among the Malays.

Table 8. Relationship between religion \& organ donation

\begin{tabular}{lll}
\hline & Organ Donation & Religion \\
\hline Pearson Correlation & 1 & $.485^{* *}$ \\
Sig. (2-tailed) & & .000 \\
$\mathrm{~N}$ & 74 & 74 \\
\hline
\end{tabular}

**. The relationship is significant at 0.01 (2-tailed)

Referring to Table 8, a Bivariate Correlation was conducted between religious factors and Malay donors. The hypothesis indicated a positive relationship between the Independent Variable and the Dependent Variable. Based on these results, it is clear that the shortage of organ donors is associated with the Malay religious factors as the value of $r=.485$ and $p>.05(p=0.000)$. This means that hypothesis showed that the amount is positive and acceptable.

$\mathrm{H} 2$ : There is a correlation between the factor of awareness and the shortage of organ donors among the Malays. 
Table 9. Relationship between awareness \& organ donation

\begin{tabular}{lll}
\hline & Organ Donation & Awareness \\
\hline Pearson Correlation & 1 & .160 \\
Sig. (2-tailed) & & .172 \\
$\mathrm{~N}$ & 74 & 74
\end{tabular}

Table 9 shows the Bivariate Correlation on the factor of awareness of the Malays on organ donation. The hypothesis showed no significant relationship exist between the Independent Variable and Dependent Variable. The result found that the lack of organ donation among the Malays is not influenced by awareness as $r=.160$ and $p>.05(p=0172)$. Therefore, this hypothesis can not be accepted as there is no or low significance for the two variables.

H3: There is a significant relationship between the factor of perception and the shortage of organ donors among the Malays.

Table 10. Relationship between perception/view \& organ donation

\begin{tabular}{lll}
\hline & Organ Donation & Perception \\
\hline Pearson Correlation & 1 & $.441^{* *}$ \\
Sig. (2-tailed) & & .000 \\
$N$ & 74 & 74 \\
\hline
\end{tabular}

**. The relationship is significant at 0.01 (2-tailed)

Based on Table 10, a bivariate correlation was performed between the factor perception / opinion and organ donation among the Malays. This hypothesis indicated a positive relationship between the Independent Variable (IV) and the Dependent Variable (DV). The study clearly illustrates that the shortage of organ donors Malay is influenced by perception as $\mathrm{r}=.441$ and $\mathrm{p}<.05(\mathrm{p}=0.000)$ therefore this hypothesis can be accepted for use.

\subsection{Domination of Independent Variables}

Table 11. Summary of the model

\begin{tabular}{lllll}
\hline Model & $\mathrm{R}$ & $\mathrm{R}$ Square & Adjusted $R$ Square & Std. Error of the Estimate \\
\hline 1 & $.608^{\mathrm{a}}$ & .369 & .342 & 2.51795 \\
\hline
\end{tabular}

a. Predictors: (Constant), Religion, Awareness, Perception

b. Dependent Variable: Organ Donation

Table 12. Anova (b)

\begin{tabular}{lllllll}
\hline Model & & Sum of Squares & Df & Mean Square & F & Sig. \\
\hline $\begin{array}{l}1 \\
\text { gression }\end{array}$ & 259.977 & 3 & 86.659 & 13.668 & $.000^{\mathrm{a}}$ \\
Residual & 443.807 & 70 & 6.340 & & \\
Total & 703.784 & 73 & & & \\
\hline
\end{tabular}

a. Predictors: (Constant), Religion, Awareness,Perception

b. Dependent Variable: Organ Donation

Table 13. Coefficients (a)

\begin{tabular}{|c|c|c|c|c|c|c|}
\hline \multirow{3}{*}{ Model } & & \multicolumn{2}{|c|}{$\begin{array}{l}\text { Unstandardized } \\
\text { Coefficients }\end{array}$} & $\begin{array}{l}\text { Standardized } \\
\text { Coefficients }\end{array}$ & & \multirow[b]{3}{*}{ Sig. } \\
\hline & & \multirow[t]{2}{*}{ B } & $\mathrm{S}$ & & \multirow[t]{2}{*}{$\mathrm{t}$} & \\
\hline & & & Error & Beta & & \\
\hline \multirow[t]{4}{*}{1} & (Constant) & 2.978 & 3.130 & & .952 & .345 \\
\hline & Religion & .825 & .193 & .526 & 4.274 & .000 \\
\hline & Awareness & -.277 & .162 & -.205 & -1.711 & .092 \\
\hline & Perception & .345 & .101 & .335 & 3.413 & .001 \\
\hline
\end{tabular}

a. Dependent Variable: Organ Donation 
This study used Multiple Regression Analysis to identify which of the three factors (religion, awareness and perception) is the major contributor to the shortage of organ donation among the Malays. Based on Table 11, 12 $\& 13$, religious factors and awareness contributed the most to the lack of organ donation, in which specifically, religion is the most dominant factor followed by perception. Obviously, the awareness factor is not applicable as a result as the analysis found that the result is Beta - .205.

\section{Conclusion}

Organ donation has become an issue due to the lack of individuals coming forward as donors. In Malaysia, between the three main races, Malays were the least involved with organ donation compared to other communities such as the Indians and Chinese. Based on the findings, the main deterrent of organ donation is religious factors that limit their action to be directly involved in organ donation activities. The majority of them believe that Islam does not allow them to do so. This happened because of the lack of transparent disclosure or discussion on this issue whereas Islam itself calls for us to do all we can in order to benefit other people, let alone to save the life of a person. This is a direct result of the lack of exposure or their knowledge on this issue. Thus, it is recommended that a comprehensive discussion should be undertaken to change the perception of the Malay community on the issue of organ donation. The role of various parties including officials and religious leaders should be exercised by mobilizing a variety of science programs such as forums, seminars, campaigns and so on, in all walks of life including schools, tertiary institutions, organizations, villages, mosques and more, in order to change public perception of organ donation from an Islamic perspective. In overall, it can be concluded that the primary factor of the Malay communities' lack of organ donation is concerned with matters of religion, followed by their own perception or view of the activity. It is hoped with the findings of this study and follow-up of the parties concerned, the number of organ donors among the Malays in particular, as well as Malaysians generally, can be further increased in response to the slogan of "1Malaysia" in which everyone act as one race; as Malaysian citizens who go through the thick and thin together.

\section{References}

Alashek WA., Ehtuish EF., Elhabashi A., Emberish W., \& Mishra A. Reasons for Unwillingness of Libyans to Donate Organs after Death. Original Article, 110-113.

Bilgin N. (1999). The Dilemma Of Cadaver Organ Donation. Transplant Proc, 31, 3265. http://dx.doi.org/10.1016/S0041-1345(99)00719-8

Cheng IK. (1992). Special Issues Related To Transplantation In Hong Kong. Transplant Proc, 24, 2423-2425.

Franklin C. Barcellos., Cora Luiza Araujo., \& Juvenal Dias da Costa. (2005). Organ Donation: a $\begin{array}{lllll}\text { population-based } & \text { study. } & \text { Clinical } & \text { Transplantation, } & 19,\end{array}$ http://dx.doi.org/10.1111/j.1399-0012.2005.00280.x

Gross, T., Martinoli, S., Spagnoli, G., Badia, F., \& Malacrida, R. (2001). Attitudes and Behavior of Young European Adults Towards the Donation of Organs - a call for better information. American Journal of Transplantation, 1, 74-81. http://dx.doi.org/10.1034/j.1600-6143.2001.010114.x

Gupta, A., Jain, S., Jain, T., \& Gupta K. (2009). Awareness and Perception Regarding Eye Donation in Students of a Nursing College in Bangalore. Indian Journal of Community Medicine, 34(2), 122-125. http://dx.doi.org/10.4103/0970-0218.51235

H., Bilgel, G. Sadikoglu, \& N. Bilgel. (2006). Transplantationsmedizin, 18. Jahrg., S. 91.

H. Khalaf, \& M.I.M. Al Sebayel. (2004). Knowledge and Attitude of Intensivists Toward Organ Donation in Riyadh, Saudi Arabia. Transplantation Proceeding, 36, 1883-1884. http://dx.doi.org/10.1016/j.transproceed.2004.08.147

Heshmatollah Shahbazian, Amir Dibaei, Maryam Barfi, John D. Jasper, \& David A. Asch. (2004). Professional And Public Attitudes Toward Incentives For Organ Donation. Leonard Davis Institute, 9(5).

Hien Phama, \& Clarence Spignerb. (2004). Clin Transplant. Blackwell Munksgaard, 18, 707-715.

Jorge S. López Martínez, María Jesús Martín López, Barbara Scandroglio, \& José Manuel Martínez García. (2008). Family perception of the process of organ donation. Qualitative psychosocial analysis of the subjective interpretation of don.... The Spanish Journal of Psychology, 11(1).

Malhotra, N. K. (2004). Marketing Research: an applied orientation (4th ed.). Upper Saddle River, NJ: Prentice Hall.

Organ Donation And Transplantation In Germany. (2006). National Transplant Centres Activities, 181-185. 
Organ Donation Share Life By Donating Your Organs And Tissues. (2001). The Journal of the American Medical Association, 286(1), 124. http://dx.doi.org/10.1001/jama.286.1.124

Pham, H., \& Spigner, C. (2004). Knowledge And Opinions About Organ Donation And Transplantation Among Vietnamese Americans In Seattle, Washington: a pilot study. Clinical Transplantation, 18, 707-715. http://dx.doi.org/10.1111/j.1399-0012.2004.00284.x

Sekaran U. (2007). Research Methods for Business: a skill building approach. John-Wiley \& Son.

Siminoff L. A., Gordon N., Hewlett J., \& Arnold R. M. (2001). Factors Influencing Families Consent For Donation Of Solid Organs For Transplantation. Jama, 286, 71. http://dx.doi.org/10.1001/jama.286.1.71

Tabachnick, B. G., \& Fidell, L. S. (2007). Using multivariate statistics (5th ed.). Boston: Pearson Education.

Thomas Grossa, B., Sebastiano Martinolia, Giulio Spagnolia, Franco Badiac, \& Roberto Malacridac. (2001). American Journal of Transplantation, 1, 74-81. http://dx.doi.org/10.1034/j.1600-6143.2001.010114.x

Wylie, M., Siddiqui, M., \& Hazel, J. (2001). Organ and Tissue Donation: Canadian Public Awareness, Knowledge and Attitude. Environics Research Group.

Y. Al-Mosalamani, H. El-Shoubaki, \& A. Bener. (2006). Factors Influencing Organ Donation and Transplantation in State of Qatar. Transplantationsmedizin, 18, 97-103. 